\title{
THE INFLUENCE OF GESTATIONAL AGE AND BIRTH WEIGHT OF THE NEWBORN ON TOOTH ERUPTION
}

\author{
A INFLUÊNCIA DA IDADE GESTACIONAL E DO PESO DO RECÉM-NATO NA ERUPÇÃO \\ DENTÁRIA
}

Sandra Regina Piovezani RAMOS ${ }^{1}$, Renato Cordeiro GUGISCH², Fabian Calixto FRAIZ²

1- Specialist in Pediatric Dentistry.

2- Assistant Professor. Dental School - Federal University of Paraná (UFPR).

Corresponding address: Renato Cordeiro Gugisch - Curso de Odontologia da Universidade Federal do Paraná - Departamento de Estomatologia - Rua Moyses Marcondes 181, apto 502 - Curitiba - Paraná - Brasil. Cep.: 80030-410 - Fone: (41) 32532107

renatogugisch@uol.com.br

Received: December 17, 2005 - Modification: April 26, 2006 - Accepted: June 28, 2006

\begin{abstract}
$O$

bjective: The aim of the present study was to compare the beginning of eruption of the first deciduous tooth in preterm infants ( $<38$ weeks) with full-term infants (38 and 42 weeks) of normal birth weight $(32.500 \mathrm{~g})$, low birth weight $(<2.500 \mathrm{~g})$ and very low birth weight $(<1.500 \mathrm{~g})$, in order to evaluate if premature birth and low birth weight would affect tooth eruption. Methods: The neonatal records and the moment of eruption of the first deciduous tooth of 146 infants - 77 preterm infants and 69 full-term infants, ranging from 5 to 36 months old, of both genders - were recorded. All of them were under care at the Pediatric Ambulatory of Hospital Universitário Evangélico at Curitiba - Parana. Data were analyzed considering biological age and post-conception, or corrected, age - which is the gestational age plus the infant's chronological age at the month of eruption of the first deciduous tooth. Results: Results showed that when chronological age is considered, tooth eruption in preterm and very low birth weight infants is importantly delayed. However, when corrected age is considered, no statistically significant differences were found among groups. Conclusion: The delayed eruption may be related to the premature birth and not to a delay in dental development.

Uniterms: Tooth eruption; Infanty, low birth weight; Gestational age; Premature children; Dentition, primary.
\end{abstract}

\section{RESUMO}

bjetivos: O objetivo do presente estudo foi comparar o início da erupção do primeiro dente decíduo em crianças nascidas prematuras (<38 semanas) e a termo (38-42 semanas), com peso normal $\left({ }^{3} 2.500\right.$ g), baixo peso ( $<2.500$ g) e muito baixo peso ( $<$ 1.500 g), para avaliar se a erupção dentária é afetada por prematuridade e baixo peso ao nascimento. Métodos: Foram anotados os registros neonatais e o início da erupção do primeiro dente decíduo de 146 crianças, 77 prematuras e 69 à termo, na faixa etária de 5 a 36 meses, sem distinção de sexo, que se encontravam em acompanhamento médico no Ambulatório de Pediatria do Hospital Universitário Evangélico de Curitiba - Paraná. Para análise dos dados foi considerada a idade biológica, pósconcepção ou corrigida - idade gestacional mais a idade cronológica da criança no mês que erupcionou o primeiro dente. Resultados: Os resultados mostraram que, de acordo com a idade cronológica, as crianças prematuras e com muito baixo peso ao nascimento tiveram um significante atraso na erupção dental. Entretanto, quando considerada a idade corrigida, não foi encontrada diferença estatisticamente significante entre os grupos. Conclusão: $O$ atraso na erupção pode ser simplesmente devido ao nascimento precoce e não a um desenvolvimento dental atrasado.

Unitermos: Erupção dentária; Recém nascido de baixo peso; Idade gestacional; Crianças prematuras; Dentição decídua. 


\section{INTRODUCTION}

The time of formation, calcification and eruption of the deciduous teeth is subject, like every biological process, to several individual variations. Nevertheless, under normal conditions, the time, sequence and chronology of the biological events follow a regular cycle.

This process may be disrupted in preterm infants by nutritional deficiencies, exposure to certain medicaments ${ }^{10,24}$ and traumatic oral manipulations ${ }^{25,29}$.

The moment when deciduous teeth erupt on preterm infants has not been established accurately. Studies suggest that birth is the stimulus for tooth eruption and that eruption time is the same in preterm infants as for full-term infants ${ }^{26}$

There are several factors that cause premature childbirth: too young mothers, low socioeconomic level, intrauterine malnutrition, cardiopathy, incompatibility of the Rh factor, previous placenta, rubella, diabetes, multiple childbirth, abuse of smoking, among others ${ }^{1,19}$.

Premature childbirth is the most frequent cause of low birth weight ${ }^{24}$. Preterm infants are at disadvantage because their internal organs are immature, with a higher risk to develop respiratory illness, hyaline membrane diseases, hyperbilirubinemia, hypocalcemia, anemia and other alterations that affect health and growth ${ }^{15,17}$.

Many studies about the growth and development of preterm infants with low birth weight indicate that, although some complications may be present on the physical growth some time after birth, they are usually corrected by catchup growth (the growth that occurs at a higher rate than estimated for the age and gender of the child in response to nutritional rehabilitation ${ }^{11,16}$. However, although the physical development of preterm infants has been well investigated, there are few studies about the impact of premature birth and its effects on the dental development and the oral cavity of infants.

The main purpose of this article is to detect changes in the moment of tooth eruption in preterm infants with low birth weight, seeking to interpret the advance or delay of the eruption in relation to the chronological age of the child.

\section{SUBJECTS AND METHODS}

The present study used a sample of 146 healthy children aged 5 to 36 months old, of both genders, with at least one tooth erupted, under routine care at the Pediatric Ambulatory of Hospital Universitário Evangélico at Curitiba-Paraná.

The infants were selected among those who attended the ambulatory accompanied by their parents or somebody responsible for them. The interviews were made from March to July of 1998. In order to collect the data, a form especially developed for the research was used, in which the following information was registered: identification of the child (age and gender), identification of parents, neonatal data (gestational age, birth weight) obtained from medical records, data about tooth eruption (month when the first deciduous tooth erupted and which tooth was it).
The data were collected from the medical records, immunization records or the pediatric record. The researcher also examined the infants and talked to their parents. The infants were catalogued according to the gestational age as preterm infants and full-term infants (according to $\mathrm{WHO})^{22}$ and according to the birth weight as adequate birth weight (equal or superior to 2.500g), low birth weight (below 2.500g) and very low birth weight (below 1.500g) ) $^{1,6,17,19,22}$.

The cases in which there were doubts concerning the correct period of eruption of the first deciduous teeth were excluded in order to assure reliability of the collected data.

For the purpose of this survey and according with the literature, tooth eruption was defined as the first clinical evidence of the tooth's structure visible in the oral mucous membrane $\mathrm{T}^{-7,11,12,14,20,21,26,28}$.

The month when the first deciduous tooth erupted was registered according to the chronological age of the child, i.e., from the moment of birth. For analysis of data, the biological age, post-conception age or corrected age (gestational age + chronological age of the infant in the month when the first tooth erupted) were also taken into account.

A single interviewer made the interviews, with consent of the person responsible for the infant.

Data were inserted into a software named EPI INFO, which is in public domain ${ }^{9}$. Descriptive analysis of the presented data was used through tables. For comparison of data, correlated with eruption of the first deciduous tooth, the parametric Student's t test and non-parametric MannWhitney test were used (on the software "Primer of Biostatistics”), for independent samples.

The minimum significance level (or probability of significance) adopted was 5\% (0.05).

\section{RESULTS AND DISCUSION}

Many efforts have been made in order to increase the knowledge about tooth eruption, not only about the chronology and sequence of eruption but also about the causes that may interfere with the eruptive process.

Literature suggests that factors like race, gender and physical development may influence tooth eruption ${ }^{12}$. As preterm birth and low birth weight may influence the physical development in general, it is possible that dental development may also be influenced.

Preterm infants are not fully developed by the time of their birth. Their chronological age does not correspond to their correct biological age. In the present study, in order to achieve a significant comparison with full-term infants, the age of the preterm infants was corrected to the preterm birth.

Table 1 show that, considering the chronological age, preterm infants show a delay in the time of eruption of the first deciduous tooth when compared to full-term infants, with statistically significant difference $(\mathrm{p}=0.004)$. However, when the corrected age is considered there was no statistically significant difference (Table 2) ( $p=0.997)$.

Our results are similar with previous studies presented 
by Golden, et al. ${ }^{13}$ and Seow, et al. ${ }^{26}$.Nevertheless, Viscardi, et al. ${ }^{29}$ noted that $40 \%$ of prematurely born infants had their teeth erupted on time, whereas the remaining $60 \%$ had their teeth erupted later, even taking into account the corrected age. The author suggests that nutritional factors and other complications related to preterm birth such as infants who need sustained mechanic ventilation contribute to delay the eruption of the first teeth, although Fadavi, et al. ${ }^{11}$ have not found a significant correlation between the time of intubation and the delayed eruption.

Preterm infants usually have low birth weight ${ }^{27}$, which may be related to a shorter gestational period and to mother's malnutrition $^{18}$. They tend to have many serious medical problems during the neonatal period that may affect the development of the oral tissue ${ }^{23}$.

Tables 3 and 4 show the correlation between eruption of the first deciduous tooth and the infant's birth weight, independently of the gestational category.
The results show a significant relation between the birth weight and the time of eruption of the first tooth when the chronological age is used (Table 3). Infants whose birth weight was lower than $1,500 \mathrm{~g}$ had their first tooth erupted later, when compared to those whose birth weight was between $1,500 \mathrm{~g}$ and $2,499 \mathrm{~g}(\mathrm{p}=0.010)$ and to those whose birth weight was equal or superior to $2,500 \mathrm{~g}(\mathrm{p}<0.0001)$. However, when the corrected ages were used, no statistically significant differences were found in the three weight groups (Table 4).

Alvarez $^{2}$ (1995); Alvarez, et al. ${ }^{4}$ (1988), Alvarez, et al. ${ }^{3}$ (1990) noticed that poorly nourished infants showed a significant delay in the eruption of the primary dentition.

Infante and Owen ${ }^{14}(1973)$ related the time of the eruption of the first deciduous tooth with the child's growth and suggested that the nutritional status may significantly affect the primary dentition's eruption.

This positive relation between tooth eruption and body

TABLE 1- Comparison between the gestational category and the chronological age of eruption of the first deciduous tooth

\begin{tabular}{lcccc}
\hline CATEGORY & NUMBER & $\begin{array}{c}\text { AGE } \\
\text { (weeks) }\end{array}$ & STANDARDDEVIATION & MEDIAN \\
\hline Preterm & 77 & 34.9 & 11.1 & 34.8 \\
Full-Term & 69 & 301 & 10.2 & 26.1 \\
TOTAL & 146 & 32.6 & 10.9 & 30.4 \\
\hline
\end{tabular}

TABLE 2- Comparison between gestational category and corrected age of eruption of the first deciduous tooth

\begin{tabular}{lcccc}
\hline CATEGORY & NUMBER & $\begin{array}{c}\text { AGE } \\
\text { (weeks) }\end{array}$ & STANDARD DEVIATION & MEDIAN \\
\hline Preterm & 77 & 69.0 & 10.4 & 67.8 \\
Full-Term 6 & 9 & 69.0 & 10.1 & 66.1 \\
TOTAL & 146 & 69.0 & 10.2 & 67.4 \\
\hline
\end{tabular}

$(p=0.997)$ non significant

TABLE 3- Comparison between birth weight and chronological age of eruption of the first deciduous tooth

\begin{tabular}{lcccc}
\hline \multicolumn{1}{c}{$\mathbf{0}$} & NUMBER & $\begin{array}{c}\text { AGE } \\
\text { (weeks) }\end{array}$ & STANDARDDEVIATION & MEDIAN \\
\hline Below 1,500 & 17 & 37.9 & 8.9 & 34.8 \\
Between 1,500 and 2,499 & 54 & 33.3 & 11.4 & 30.4 \\
2,500 and more & 75 & 30.9 & 10.7 & 30.4 \\
TOTAL & 146 & 32.6 & 10.9 & 30.4 \\
\hline
\end{tabular}

$1 \times 2(\mathrm{p}=0.010)$ significant

$1 \times 3(p<0.0001)$ significant

$2 \times 3(p=0.144)$ non significant
1 - below $1,500 \mathrm{~g}$
2 - between 1,500 and $2,499 \mathrm{~g}$
3 - equal or superior to $2,500 \mathrm{~g}$ 
growth was also verified by Seow ${ }^{25}$ (1984) who compared the average eruption's time between low birth weight and normal birth weight infants and verified that the eruption occurred significantly sooner on normal birth weight infants.

The gain of weight after birth is significantly related to the eruption time of the entire deciduous dentition. Seow, et al. ${ }^{26}$ (1988), using the chronological age, verified that very low birth weight infants showed few erupted teeth at the age between 6 and 11 months, and between 12 and 17 months in comparison with low birth weight infants and normal birth weight infants. Nevertheless, at the age between 18 and 23 months and after 24 months they did not find any expressive difference between the three birth weight groups, indicating that the normal pattern of eruption corresponding to age was corrected by the catch-up growth after the second year of life; Fadavi, et al. ${ }^{11}$ (1992) also observed the same fact. However, when biological age is taken into account, preterm infants do not show significant differences regarding the number of erupted teeth in relation to the other three groups.

Andrade and Bezerra ${ }^{5}$ (1998) did not find any delay in the chronology of eruption of deciduous teeth in high-risk infants, among them preterm infants (born before the $37^{\text {th }}$ week) and low birth weight infants (weight inferior to 2,500g). However, they attributed this circumstance to the fact that they did not study infants whose birth weight was very low. They studied only infants with low birth weight and normal birth weight who did not show any difference in eruption.

The average chronological age of eruption of the first deciduous tooth was 34.3 (10.3) weeks for male infants and 31.4 (11.2) weeks for female infants. When the corrected age was taken into account, eruption occurred at the 70.6th (10.3) week for male infants and at the 67.8th (10.1) week for female infants. Such results show that there was no significant relation between the gender of infants and their chronological age in the average $(\mathrm{p}=0.194)$ nor the corrected age $(\mathrm{p}=0.183)$. These facts were in agreement with those found in the works of Falkner ${ }^{12}$ (1957), Robinow ${ }^{20}$ (1973), Fadavi, et al. ${ }^{11}$ (1992), Viscardi, et al. ${ }^{29}$ (1994), Caixeta ${ }^{8}$ (1995).

Knowledge on the normal eruption time of teeth is of clinical importance for accurate diagnosis of various local and systemic conditions that may affect tooth eruption such as supernumerary teeth, impacted teeth, cysts and tumors, which may cause local delayed eruption ${ }^{26}$.
According to Noren ${ }^{18}$ (1983), preterm and low birth weight infants comprise approximately $6 \%$ of all live births.

The results of the present study indicate that preterm infants with very low birth weight are highly exposed to the risk of a delayed eruption of the first primary tooth when chronological age is used. Nevertheless, when corrected age is used, the facts show that there are no significant differences on the time of eruption, indicating that preterm infants whose birth weight is very low may have the eruption of their first deciduous tooth delayed because of their preterm births and not due to a delay in dental development.

Considering that there are few studies in the literature about the influence of neonatal disturbances and nutritional factors over the period of tooth eruption, further studies should be carried out in order to evaluate and report possible changes on the pattern of regular eruption of the primary dentition. Moreover, works in order to improve the prenatal, neonatal and postnatal care and to propose more efficient conducts aiming to avoid the dental and systemic changes of children can be accomplished by health care programs to mothers.

\section{CONCLUSIONS}

According to the methodology used and based on the results achieved, the following conclusions were reached:

1. According to the chronological age, preterm infants showed a delay in the eruption time of the first deciduous tooth when compared to full-term infants. When the corrected age was used, there were no significant differences between groups;

2. Considering the chronological age, very low birth weight infants (below 1,500g) showed a significant delay in the eruption of the first deciduous tooth when compared to low birth weight infants and to normal birth weight infants.

3. No significant correlation was found between the gender of infants and the time of eruption of the first deciduous tooth when considered the chronological age and the corrected age.

TABLE 4- Comparison between birth weight and corrected age of eruption of the first deciduous tooth

\begin{tabular}{|c|c|c|c|c|}
\hline WEIGHT (g) & NUMBER & $\begin{array}{c}\text { AGE } \\
\text { (weeks) }\end{array}$ & STANDARD DEVIATION & MEDIAN \\
\hline Below 1,500 & 17 & 68.6 & 7.8 & 67.8 \\
\hline Between 1,500 and 2,499 & 54 & 68.5 & 10.9 & 67.4 \\
\hline 2,500 and more & 75 & 69.4 & 10.3 & 67.4 \\
\hline TOTAL & 146 & 69.0 & 10.2 & 67.4 \\
\hline
\end{tabular}

\footnotetext{
$1 \times 2(p=0.974)$ non significant

1 - below $1,500 \mathrm{~g}$

$1 \times 3(p=0.513)$ non significant

2 - between 1,500 and $2,499 \mathrm{~g}$

$2 \times 3(p=0.581)$ non significant

3 - equal or superior to $2,500 \mathrm{~g}$
} 


\section{REFERENCES}

1- Alcântara P, Marcondes E. Pediatria básica. 6. ed. São Paulo: Sarvier; 1978.

2- Alvarez JO. Nutrition, tooth development, and dental caries. Am J Clin Nutr. 1995;61(suppl.):4105-65.

3- Alvarez JO, Eguren JC, Caceda J, Navia JM. The effect of nutritional status on the age distribution of dental caries in the primary teeth. J Dent Res.1990;69(9):1564-6.

4- Alvarez JO, Lewis CA, Saman C, Caceda J, Montalvo J, Navia J. Chronic malnutrition, dental caries and tooth esfolation in Peruvian Children aged 3-9 years. J Clin Nutr. 1988;48:368-72.

5- Andrade IR, Bezerra ACB. Estudo longitudinal comparativo da cronologia de erupção em crianças. JPB \& Odontologia do Bebê. $1998 ; 1(2): 41-7$

6- Avery GB, Fletcher MA, MacDonald MG. Pathophysiology and management of the newborn. Philadelphia: J. B. Lippincott; 1994.

7- Barret MJ, Brown T. Eruption of decíduos teeth in Australian aborígenes. Aust Dent J. 1966;11:11-43.

8- Caixeta FF. Estudo dos defeitos de esmalte e padrão de erupção dentária em crianças prematuras, na faixa de 06 meses a 06 anos de idade. São Paulo, 1995. [Master Dissertation - Faculdade de Odontologia da Universidade de São Paulo].

9- Dean AG, Dean AJ, Burton AH, Dicker RC. Epi info, version 5: a word processing, database, and statistics program for epidemiology on micro-computers. Atlanta: Centres for Disease Control; 1990.

10- Drumond BK, Ryan S, O’Sullivan EA, Condgdon P, Curzon MEJ. Enamel defects of the primary dentition and osteopenia of prematurity. Pediatr Dent. 1992;14(2):19-21.

11- Fadavi S, Punwani IC; Adeni S; Vidysagar D. Eruption pattern in the primary dentition of premature low-birth-weight children. ASDC J Dent Child. 1992;59:120-2.

12- Falkner F. Deciduous tooth eruption. Arch Disease Childhood. 1957;32:386-91.

13- Golden NL, Takieddine F,Hirsch VJ. Teething age in prematurely born infants. Am J Dis Child. 1981;135(10):903-4.

14- Infanti PF, Owen GM. Relation of chronology of deciduos tooth emergence to leight, weight and head circunference in children. Archs Oral Biol. 1973;18(11):1411-7.

15- Kliegman RM, Behrman RE. The high risk infant. In: Behrman RE, Vaughn III VC. (ed.) Nelsontextbook of pediatrics. Philadelphia: WB Saunders; 1987. p. 373-85.

16- Loevy HT, Raval DS, Aneybuno M, Goldberg AF. Oral development in children with very low birth weight. [abstract 608]. J Dent Res.1989;68(sp.Issue):942.

17- Marcondes E. Pediatria básica. São Paulo: Sarvier; 1994.

18- Noren JG. Enamel structure in deciduos teeth from low-birthweight infants. Acta Odontol Scand. 1983;41(6):355-62.

19- Rezende J. Obstetrícia fundamental. Rio de Janeiro: Guanabara Koogan; 1992. p.340-51.

20- Robinow M. The eruption of deciduos teeth. J Trop Pediatr Environ Child Health. 1973;19:200-5.
21- Sandler HC. The eruption of deciduos teeth. J Pediatr.1944;25(1):140-7.

22- Segre CAM. Recém-Nascido. São Paulo: Sarvier; 1985. p.3-179.

23- Seow WK. Effects of preterm birth on oral growth and development. Aust Dent J. 1997;42(2):85-91.

24- Seow WK, Brown JP, Tudehope DI, O’Callaghan M. Dental defects in the deciduos dentition of premature infants with low birth weight and neonatal rickets. Pediatr Dent.1984;6:88-92.

25- Seow WK., Brown JP, Tudehope DI, O’Callaghan M. Development defects in the primary dentition of low birth-weight infants: adverse effects of laryngoscopy and prolonged endotracheal intubation. Pediatr Dent. 1984;6:28-31.

26- Seow WK, Humphrys C, Mahanonda R, Tudehope DI. Dental eruption in low birth-weight prematurely born children: a controlled study. Pediatr Dent. 1988;10(1):39-42.

27- Seow WK, Humphrys C, Tudehope DI. Increased prevalence of developmental dental defects in low birth-weight, prematurely born children: a controlled study. Pediatr Dent.1987;9(3):221-5.

28- Trupkin DP. Eruption patterns of the first primary tooth in infants who were underweight at birth. ASDC J Dent Child.1974;41:279-82.

29- Viscardi RM, Romberg E. Abrams RG. Delayed primary tooth eruption in premature infants: relationship to neonatal factors. Pediatr Dent. 1994;16(1):23-8 